Arab Univ. J. Agric. Sci., Ain Shams Univ., Cairo, 13(2), 249 - 268, 2005

\title{
CULTURAL, MORPHOLOGICAL, PHYSIOLOGICAL AND MOLECULAR STUDIES ON SOME STREPTOMYCETE ISOLATES
}

[15]

\begin{abstract}
In this study, three isolates of Streptomyces isolated from Egyptian soil at Giza Governorate and belonging to red series were identified based on their cultural, morphological and physiological characters. According to the key proposed by Pridham and Tresner (1974), the experimental isolates ST55, ST71 and ST86 appeared to be related to $S$. lincolnensis, $S$. venezuelae and $S$. umbrinus, respectively. In addition, random amplified polymorphic DNA (RAPD)-polymerase chain reaction (PCR) was used to amplify the DNA genome of the three applied isolates and an identified strain to determine their fingerprints. This was carried out using 10decamer oligonucleotides, i.e., OP-A02, OP-D01, OP-D02, OP-D05, OP-D06, OPD07, OP-D08, OP-D11, OP-D18 and OP-D20. The PCR amplified products were detected by electrophoresing on $1.5 \%$ agarose gel and visualized by staining in ethidium bromide and UV trasilluminator. Results showed that the same oligonucleotide flanking fragments differed from one isolate to another with different sizes. Monomorphic and polymorphic fragments were amplified confirming the molecular relationships as well as the genetic diversity between the four applied strains of Streptomyces. Based on the statistical analysis of RAPD-PCR polymorphisms a degree of similarities ranged from 33.9 to $59.2 \%$ was found. Furthermore, fragment(s), whatever absent or present, were found to be unique molecular markers and could be used for characterization of some isolates. This result supported the idea for using the RAPD-PCR technique for classification of Streptomyces isolates.
\end{abstract}

Key words: Streptomyces, Identification, RAPD-PCR, Molecular markers, Fingerprint

\section{INTRODUCTION}

Streptomycetes are gram positive bacteria with high guanine plus cytosine content in their DNA. They exist mainly as spores in their natural habitat, soil, and form vegetative under favorable growth conditions. They constitute the largest actinomycete group in a number of soil (Goodfellow and Simpson, 1987 and Srinivasan et al 1991), and are nonfastidious organisms, which are able to degrade complex biological compounds like cellulose, lignin and chitin, and are

1- Department of Agricultural Microbiology, Faculty of Agriculture, Zagazig University, Zagazig, Egypt 
satisfied with an inorganic nitrogen source. They are known as producers of many secondary metabolities, such as antibiotics, herbicides, insecticides and enzymes (Srinivasan et al 1991 and Anderson et al 1998). Also, Strohl (1997) mentioned that numerous new bioactive molecules were discovered, in the last decades, through large screening programs of these bacteria, and these substances found their way into various clinical uses ranging from control of infection to cancer treatment.

Thus, strptomycetes are renowned for production of array industrially important metabolites, therefore, the isolation, identification and characterization processes of Streptomyces isolates are still very important in search for new strains and/or novel metabolites with economic interest in diverse fields.

In the last ten years, different studies have been reported using random amplified polymorphic DNA (RAPD)polymerase chain reaction (PCR) technique for identification, characterization and assessment of genetic diversity between isolates of Streptomyces (Porteous et al 1994; Mehling et al 1995; Malkawi et al 1999; Nava et al 2001; Rintala et al 2002; Tolba et al 2002; Wirth and Ulrich, 2002; Cook and Meyers, 2003; Raad et al 2003 and Sony et al 2004).

In Egypt, numerous researches were performed on these bacteria in diverse branches of agriculture (Saleh et al 1985; Saleh et al 1990; Zaki et al 1993 Mohamed, 1998 and Mohamed et al 2000), medicine, pharmaceutics and others, but little studies were carried out using RAPD-PCR technique as a molecular tool for investigating the genetic variation between isolates of Streptomyces from soil (Mohamed et al 2000; Mohamed et al 2001 and Mahfouz and Mohamed, 2002).

Therefore, in this study, three Streptomyces isolates, belonged to the red series were identified and their DNA fingerprinting was determined via RAPDPCR analysis.

\section{MATERIAL AND METHODS}

\section{Source of streptomycete isolates}

Three streptomycete isolates named ST55, ST71 and ST86, isolated from soil at Giza Governorate in Egypt were kindly obtained from, Department of Agricultural Microbiology, Institute of Soil, Water and Environment Research, ARC, Giza, Egypt. These halotolerant isolates having the ability to grow on the growth medium supplemented with $7 \% \mathrm{NaCl}$ and belonging to the red series group of Streptomyces. In addition, the $S$. tuirus $\mathrm{Si}-4$ that identified by Mahfouz and Mohamed (2002) was used as a strain of the red series group in case of RAPD-PCR analysis.

\section{Identification of streptomycete isolates}

In this experiment, the key given by Pridham and Tresner (1974) for identification was followed. For determination of the cultural, morphological and physiological characteristics of the applied streptomycete isolates, the media and methods of the International Streptomyces Project (ISP) as described by Shirling and Gottlieb (1966) were applied. Spore chain type for each isolate was determined according to Pridham and Tresner (1974). The antibiosis activities of the applied isolates were tested using two fungi (Fusarium oxysporum F. sp. Lyco- 
persci-123 and Helminthosporium gramenium-133, 2 yeasts (Candida albicans CAIM-352 and C. tropicalis CAIM2); and 5 bacteria (Bacillus cereus-1283, B. megaterium-1066, B. mycoides -1084 , B. subtilis-1007; and Escherichia coli1319) as employed by Mohamed et al (2001). These microorganisms were obtained from Cairo MIRCEN, Faculty of Agriculture, Ain Shams University.

\section{Primers used}

In this study, a number of 10-decamer oligonucleotide primers; OP-A02, OPD01, OP-D02, OP-D05, OP-D06, OPD07, OP-D08, OP-D11, OP-D18, and OP-D20 from OPERON Technologies, Alameda, CA., kits A and D were used. The nucleotide sequences of the applied primers was as follows:

\begin{tabular}{ll}
$\underline{\text { Primer }}$ & Sequences (5'----------3') \\
\cline { 2 - 2 } OP-A02 & TGC CGA GCT G \\
OP-D01 & ACC GCG AAG G \\
OP-D02 & GGA CCC AAC C \\
OP-D05 & TGA GCG GAC A \\
OP-D06 & ACC TGA ACG G \\
OP-D07 & TTG GCA CGG G \\
OP-D08 & GTG TGC CCC A \\
OP-D11 & AGC GCC ATT G \\
OP-D18 & GAG AGC CAA C \\
OP-D20 & ACC CGG TCA C
\end{tabular}

RAPD-PCR analysis of the applied Streptomyces isolates

In order to extract the DNA genome of the three Streptomyces isolates, $50 \mathrm{ml}$ in 250-ml conical flask of starch nitrate broth medium (Waksman and Lechevalier, 1961) were inoculated separately by the Streptomyces isolates, then incubated at $28^{\circ} \mathrm{C} \pm 2$ for 6 days on a rotary shaker (160-rpm), and the mycelium was then collected and pulverized in liquid nitrogen. The nucleic acid was extracted, purified and its concentration was determined and adjusted as described by Brown (1990) and Mahfouz and Mohamed (2002) to $100 \mathrm{ng} / \mu \mathrm{l}$.

According to the method of Williams et al (1990) and Mohamed et al (2001), 10 decamer oligonucleotide primers from OPERON Technologies, Alameda, CA., kits $\mathrm{A}$ and $\mathrm{D}$, were used for amplification of the DNA genome of the three applied Streptomyces isolates. The amplification reaction conducted on a volume of $50 \mu \mathrm{l}$. PCR amplification performed in a PerkinElmer (Gene Amp PCR System 2400) for 35 cycles after initial denaturation for 4 min at $94^{\circ} \mathrm{C}$. Each cycle consisted of denaturation at $94^{\circ} \mathrm{C}$ for $1 \mathrm{~min}$, annealing at $37^{\circ} \mathrm{C}$ for $1 \mathrm{~min}$, extension at $72^{\circ} \mathrm{C}$ for 2 min. The primer extension extended to 7 min at $72^{\circ} \mathrm{C}$ in the final cycle. The PCR amplified products were detected by electrophoresing on $1.5 \%$ agarose gel in $1 \mathrm{X}$ TAE buffer at 60 volts for two hours (Sambrook et al 1989). PCR fragments visualized by staining gel in ethidium bromide $(0.5 \mu \mathrm{g} / \mathrm{ml})$ and photographed under UV light using a Polaroid camera.

Analysis was carried out by visually examination of the amplified fragments and scoring as present (1) or absent (0). The similarity coefficient (F) between isolates was defined by the formula of Nei and Li (1979). From the distance by unweighted paired-group method, arithmetic mean (UPGMA) contained in the computer program package NTSYS 1.5 (Rohlf, 1990), the phylogenetic tree was derived.

\section{RESULTS AND DISCUSSION}




\section{Isolate ST55 identification}

Results in Table (1) indicate that the Streptomyces isolate ST55 belonged to the red series group and the substrate mycelium produced yellow pigment on the standard media used. Aerial spore chains belonged to section RF and the spores were characterized by smooth surface without any ornamentation. Melanoid pigment was detected on the standard media. This isolate was characterized by good growth on Czapek's agar medium. The physiological characteristics showed that this isolate was able to utilize all used sugar except for D-mannitol and sucrose as carbon sources for growth. In addition, this isolate showed antibacterial and antifungal activities against the tested organisms used under study and no sensitivity to streptomycin $(4 \mu \mathrm{g} \mathrm{ml}-1)$ was observed.

Comparing the cultural, morphological and physiological characteristics of the Streptomyces spp in Pridham and Tresner (1974) with those of this isolate, it was very likely to be strain of $\boldsymbol{S}$. lincolnensis with slight differences in the colour of substrate mycelium, and in the utilization of D-mannitol and sucrose as carbon source for growth.

\section{Isolate ST71 identification}

Results presented in Table (2) reveal that the characteristics of Streptomyces isolate ST71 appeared to be closely resemble to $S$. venezuelae based on the description keys proposed by Pridham and Tresner (1974) with slight differences in the utilization of i-Inositol and D-mannitol as a carbon source for growth.
The cultural, morphological and physiological characteristics of the tested isolate clearly showed that the color of aerial mycelium was red (red colour series) while the reverse side of substrate mycelium was yellow. Spore chains are belong to RF section with smooth surface. No soluble pigment was produced in all standard media used. Moderate growth on Czapek's agar medium was noted. It was noted that this isolate actively utilized all of the carbon sources used for growth. It is of importance to mention that this isolate antagonized the nine test microorganisms used in this study and was affected by streptomycin $\left(4 \mu \mathrm{g} \mathrm{ml}^{-1}\right)$.

\section{Isolate ST86 identification}

Data in Table (3) show that the Streptomyces isolate ST86 belonged to the red series group and the vegetative mycelium was also pigmented with yellow colour. This isolate had RA spore chain with smooth surface. It produced a melanoid pigment, gave also an excellent growth on Czapek's agar medium and only actively utilized D-glucose, D-Xylose, LArabinose, L-Rhamnose, D-Fructose, and D-Mannitol as carbon sources for growth. This isolate showed antagonistic activity against the test organisms used. However, no growth was observed in the presence of $4 \mu \mathrm{g} \mathrm{ml}^{-1}$ streptomycin antibiotic in the medium. According to the keys proposed by Pridham and Tresner (1974), the experimental Streptomyces isolate ST86 appeared to be related to $S$. umbrinus as illustrated in Table (3) although there was a slight difference in the utilization of some carbon sources for growth and in the colour of substrate mycelium. Therefore, isolate ST86 could be considered a strain of $S$. umbrinus. 
Table 1. Cultural, morphological and physiological characteristics of streptomycete isolate ST55 compared with those of similar species reported by Pridham and Tresner (1974)

\begin{tabular}{|c|c|c|}
\hline Character & Isolate ST55 & $\begin{array}{l}\text { S. lincolnensis } \\
\text { Pridham and Tresner (1974) }\end{array}$ \\
\hline Color of aerial mycelium & Red & Red \\
\hline Spore-chain & RF & RF \\
\hline Melanoid pigment & + & + \\
\hline Spore surface & SM & SM \\
\hline Growth on Czapek's medium & Good & Excellent \\
\hline Color of substrate mycelium & Yellow & ND \\
\hline Diffusable pigments & - & ND \\
\hline \multicolumn{3}{|l|}{ Utilization of Carbon: } \\
\hline No carbon & - & - \\
\hline D-Glucose & + & + \\
\hline D-Xylose & + & + \\
\hline L-Arabinose & + & + \\
\hline L-Rhamnose & + & + \\
\hline D-Fructose & + & + \\
\hline Raffinose & + & + \\
\hline D-Mannitol & - & + \\
\hline i-Inositol & + & + \\
\hline Sucrose & - & + \\
\hline Antagonistic activity & $\begin{array}{l}\text { Antibacterial and } \\
\text { antifungal* }\end{array}$ & $\begin{array}{l}\text { Produce lincomycins A, B, C } \\
\text { and D antibacterial }\end{array}$ \\
\hline Sensitivity to Streptomycin & NS & ND \\
\hline $\mathrm{NaCl}$ tolerance & $0-7 \%$ & $\geq 7 \%$ but $<10 \%$ \\
\hline
\end{tabular}

+: Growth. -: No growth. RF: Spores in straight (R) or flexuous (F) chains.

ND: Not determined. SM: Smooth. NS: Not sensitive.

* Test organisms used: Refer to materials and methods. 
Table 2. Cultural, morphological and physiological characteristics of streptomycete isolate ST71 compared with those of similar species reported by Pridham and Tresner (1974)

\begin{tabular}{|c|c|c|}
\hline Character & Isolate ST71 & $\begin{array}{l}\text { S. venezuelae } \\
\text { Pridham and Tresner (1974) }\end{array}$ \\
\hline Color of aerial mycelium & Red & Red \\
\hline Spore-chain & $\mathrm{RF}$ & $\mathrm{RF}$ \\
\hline Melanoid pigment & - & - \\
\hline Spore surface & SM & SM \\
\hline Growth on Czapek's medium & Moderate & ND \\
\hline Color of substrate mycelium & Yellow & ND \\
\hline Diffusable pigments & - & \\
\hline \multicolumn{3}{|l|}{ Utilization of Carbon: } \\
\hline No carbon & - & - \\
\hline D-Glucose & + & + \\
\hline D-Xylose & + & + \\
\hline L-Arabinose & + & + \\
\hline L-Rhamnose & + & + \\
\hline D-Fructose & + & + \\
\hline Raffinose & + & ND \\
\hline D-Mannitol & + & - \\
\hline i-Inositol & + & - \\
\hline Sucrose & + & ND \\
\hline Antagonistic activity & $\begin{array}{l}\text { Antibacterial and } \\
\text { antifungal* }\end{array}$ & ND \\
\hline Sensitivity to streptomycin & $\mathrm{S}$ & ND \\
\hline $\mathrm{NaCl}$ tolerance & $0-7 \%$ & ND \\
\hline
\end{tabular}

+: Growth. -: No growth. RF: Spores in straight (R) or flexuous (F) chains. SM: Smooth. S: Sensitive. ND: Not determined.

* Test organisms used: Refer to Table 1. 
Table 3. Cultural, morphological and physiological characteristics of streptomycete isolate ST86 compared with those of similar species reported Pridham and Tresner (1974)

\begin{tabular}{|c|c|c|}
\hline Character & Isolate ST86 & $\begin{array}{l}\text { S. umbrinus } \\
\text { Pridham and Tresner (1974) }\end{array}$ \\
\hline Color of aerial mycelium & Red & Red \\
\hline Spore-chain & RA & RF \\
\hline Melanoid pigment & + & + \\
\hline Spore surface & SM & SM \\
\hline Growth on Czapek's medium & Excellent & Excellent \\
\hline Color of substrate mycelium & Yellow & Purple-brown \\
\hline Diffusable pigments & - & ND \\
\hline \multicolumn{3}{|l|}{ Utilization of Carbon: } \\
\hline No carbon & - & - \\
\hline D-Glucose & + & + \\
\hline D-Xylose & + & + \\
\hline L-Arabinose & + & + \\
\hline L-Rhamnose & + & + \\
\hline D-Fructose & \pm & + \\
\hline Raffinose & - & + \\
\hline D-Mannitol & + & + \\
\hline i-Inositol & - & + \\
\hline Sucrose & - & + \\
\hline Antagonistic activity & $\begin{array}{l}\text { Antibacterial and } \\
\text { antifungal* }\end{array}$ & Antibacterial \\
\hline Sensitivity to streptomycin & $\mathrm{S}$ & $\mathrm{S}$ \\
\hline $\mathrm{NaCl}$ tolerance & $0-7 \%$ & $\geq 7 \%$ but $<10 \%$ \\
\hline
\end{tabular}

+: Growth. -: No growth. RA: Spore chain in the form of open loops, hooks or greatly extended coils of wide. SM: Smooth. S: Sensitive. ND: Not determined.

* Test organisms used: Refer to Table 1 . 


\section{RAPD-PCR analysis}

The RAPD technique developed by Williams et al (1990) provides a faster and easier approach for exploring genetic polymorphism, and also requires very small amounts of DNA. RAPD markers have been successfully used in isolate analysis in some streptomycetes (Nava $\boldsymbol{e t}$ al 2001; Rintala et al 2002; Tolba et al 2002; Wirth and Ulrich, 2002; Cook and Meyers, 2003; Raad et al 2003 and Sony et al 2004).

This study aimed to use the RAPDPCR technology to obtain DNA markers for identification of some identified species from the genus Streptomyces. RAPD analysis resolved that 125 DNA fragments were amplified from the DNA of the four Streptomyces strains using ten 10-nt random primers Table (4) and Figure (5). The strains were varied in the number of PCR products as 69, 73, 76 and 68 fragments were amplified from the DNA of $S$. lincolnensis, S. venezuelae, S. umbrinus and $S$. tuirus $\mathrm{Si}-4$, respectively, (Table 5). Results in Table (7) show that the similarity between the four species ranged from $30.6 \%$ to $59.2 \%$.

In addition, 74 scorable markers from the ten primers were obtained (Table 5). Primers produced between 1 and 10 amplification products as markers (present or absent). The $S$. venezuelae showed the highest number (32) of these markers followed by $S$. umbrinus (26), S. lincolnensis (9) and S. tuirus Si-4 (7). Results in Figure (6) show that two major clusters of Streptomyces strains were found in the dendrogram. The first cluster included the $S$. lincolnensis and $S$. venezuelae.

On the other hand, the $S$. umbrinus and $S$. tuirus $\mathrm{Si}-4$ gave the second cluster.

Our results recommended the utilization of the DNA markers as a powerful tool for variety identification in Streptomyces. This is in agreement with those found by Kearley et al (1994); Mehling et al (1995); Weigler et al (1996); Klein et al (1998); Malkawi et al (1999); Mohamed et al (2001); Nava et al (2001); Tolba et al (2002); Wirth and Ulrich (2002); Raad et al (2003) and Sony et al (2004).

\section{ACKNOWLEDGMENT}

The author likes to thank Dr. Hanaiya A. El-Itriby, Deputy President of ARC and Director of Agricultural Genetic Engineering Research Institute (AGERI) and Dr. Sonya H. Mohamed, Department of Agricultural Microbiology, Institute of Soil, Water and Environment Research, ARC, Giza, Egypt for their sincere help during this study. 
Table 4. RAPD-PCR polymorphism of the three applied Streptomyces isolates using 10-decamer oligonucleotides

\begin{tabular}{|c|c|c|c|c|}
\hline \multirow{2}{*}{$\begin{array}{l}\text { Amplified } \\
\text { fragments }\end{array}$} & \multicolumn{4}{|c|}{ Streptomyces strains } \\
\hline & S. lincolnensis & S. venezuelae & S. umbrinus & S. tuirus $\mathrm{Si}-4$ \\
\hline OPA-0201 & 0 & 0 & 1 & 0 \\
\hline OPA-0202 & 0 & 0 & 1 & 0 \\
\hline OPA-0203 & 1 & 1 & 0 & 1 \\
\hline OPA-0204 & 1 & 1 & 1 & 1 \\
\hline OPA-0205 & 1 & 1 & 0 & 1 \\
\hline OPA-0206 & 0 & 0 & 1 & 0 \\
\hline OPA-0207 & 1 & 1 & 0 & 0 \\
\hline OPA-0208 & 1 & 1 & 1 & 1 \\
\hline OPA-0209 & 1 & 1 & 0 & 1 \\
\hline OPA-0210 & 1 & 1 & 1 & 1 \\
\hline OPA-0211 & 0 & 0 & 1 & 0 \\
\hline OPA-0212 & 1 & 1 & 0 & 1 \\
\hline OPA-0213 & 1 & 1 & 0 & 1 \\
\hline OPA-0214 & 0 & 1 & 1 & 1 \\
\hline OPA-0215 & 0 & 0 & 1 & 0 \\
\hline OPD-0101 & 0 & 1 & 0 & 1 \\
\hline OPD-0102 & 1 & 0 & 1 & 1 \\
\hline OPD-0103 & 1 & 1 & 1 & 1 \\
\hline OPD-0104 & 1 & 1 & 0 & 1 \\
\hline OPD-0105 & 1 & 0 & 1 & 0 \\
\hline OPD-0106 & 0 & 0 & 0 & 1 \\
\hline OPD-0107 & 0 & 1 & 0 & 0 \\
\hline OPD-0108 & 1 & 0 & 1 & 1 \\
\hline OPD-0201 & 0 & 0 & 1 & 0 \\
\hline OPD-0202 & 0 & 1 & 1 & 1 \\
\hline OPD-0203 & 1 & 1 & 1 & 1 \\
\hline OPD-0204 & 0 & 1 & 0 & 0 \\
\hline OPD-0205 & 0 & 0 & 1 & 1 \\
\hline OPD-0206 & 1 & 0 & 1 & 1 \\
\hline OPD-0207 & 0 & 1 & 0 & 0 \\
\hline OPD-0208 & 1 & 1 & 0 & 0 \\
\hline OPD-0501 & 1 & 1 & 0 & 1 \\
\hline OPD-0502 & 1 & 1 & 1 & 1 \\
\hline
\end{tabular}

Arab Univ. J. Agric. Sci., 13(2), 2005 
Table 4. Cont.

\begin{tabular}{|c|c|c|c|c|}
\hline \multirow{2}{*}{$\begin{array}{l}\text { Amplified } \\
\text { fragments }\end{array}$} & \multicolumn{4}{|c|}{ Streptomyces strains } \\
\hline & S. lincolnensis & S. venezuelae & S. umbrinus & S. tuirus $\mathrm{Si}-4$ \\
\hline OPD-0503 & 1 & 1 & 1 & 1 \\
\hline OPD-0504 & 1 & 0 & 1 & 0 \\
\hline OPD-0505 & 0 & 1 & 1 & 1 \\
\hline OPD-0506 & 0 & 1 & 0 & 0 \\
\hline OPD-0507 & 1 & 1 & 1 & 1 \\
\hline OPD-0514 & 1 & 0 & 0 & 0 \\
\hline OPD-0601 & 0 & 1 & 0 & 0 \\
\hline OPD-0602 & 1 & 0 & 1 & 0 \\
\hline OPD-0603 & 0 & 1 & 0 & 1 \\
\hline OPD-0604 & 0 & 1 & 1 & 1 \\
\hline OPD-0605 & 1 & 0 & 1 & 0 \\
\hline OPD-0606 & 0 & 1 & 0 & 1 \\
\hline OPD-0607 & 1 & 0 & 1 & 0 \\
\hline OPD-0608 & 1 & 1 & 1 & 1 \\
\hline OPD-0609 & 1 & 1 & 1 & 1 \\
\hline OPD-0610 & 1 & 0 & 1 & 1 \\
\hline OPD-0701 & 0 & 1 & 0 & 0 \\
\hline OPD-0702 & 0 & 0 & 0 & 1 \\
\hline OPD-0703 & 0 & 1 & 0 & 0 \\
\hline OPD-0704 & 1 & 0 & 0 & 1 \\
\hline OPD-0705 & 0 & 1 & 0 & 0 \\
\hline OPD-0706 & 1 & 0 & 1 & 1 \\
\hline OPD-0707 & 1 & 1 & 1 & 1 \\
\hline OPD-0708 & 1 & 0 & 1 & 1 \\
\hline OPD-0709 & 1 & 0 & 1 & 0 \\
\hline OPD-0710 & 1 & 1 & 1 & 1 \\
\hline OPD-0711 & 0 & 0 & 1 & 1 \\
\hline OPD-0712 & 1 & 1 & 1 & 1 \\
\hline OPD-0713 & 0 & 1 & 0 & 0 \\
\hline OPD-0714 & 1 & 1 & 1 & 1 \\
\hline OPD-0715 & 0 & 0 & 1 & 0 \\
\hline OPD-0716 & 0 & 1 & 0 & 0 \\
\hline OPD-0717 & 1 & 0 & 1 & 1 \\
\hline OPD-0718 & 1 & 0 & 0 & 0 \\
\hline
\end{tabular}

Arab Univ. J. Agric. Sci., 13(2), 2005 
Table 4. Cont.

\begin{tabular}{|c|c|c|c|c|}
\hline \multirow{2}{*}{$\begin{array}{l}\text { Amplified } \\
\text { fragments }\end{array}$} & \multicolumn{4}{|c|}{ Streptomyces strains } \\
\hline & S. lincolnensis & S. venezuelae & S. umbrinus & S. tuirus $\mathrm{Si}-4$ \\
\hline OPD-0719 & 0 & 1 & 1 & 0 \\
\hline OPD-0801 & 0 & 0 & 1 & 1 \\
\hline OPD-0802 & 0 & 0 & 1 & 1 \\
\hline OPD-0803 & 0 & 0 & 1 & 1 \\
\hline OPD-0804 & 0 & 0 & 1 & 1 \\
\hline OPD-0805 & 1 & 1 & 0 & 1 \\
\hline OPD-0806 & 0 & 0 & 1 & 0 \\
\hline OPD-0807 & 0 & 1 & 0 & 0 \\
\hline OPD-0808 & 1 & 0 & 1 & 1 \\
\hline OPD-0809 & 1 & 0 & 1 & 1 \\
\hline OPD-0810 & 1 & 1 & 0 & 0 \\
\hline OPD-0811 & 1 & 1 & 1 & 1 \\
\hline OPD-0812 & 0 & 0 & 1 & 1 \\
\hline OPD-0813 & 1 & 1 & 0 & 1 \\
\hline OPD-0814 & 0 & 0 & 1 & 0 \\
\hline OPD-0815 & 0 & 1 & 1 & 1 \\
\hline OPD-0816 & 1 & 0 & 1 & 0 \\
\hline OPD-0817 & 1 & 1 & 0 & 0 \\
\hline OPD-0818 & 1 & 0 & 0 & 1 \\
\hline OPD-1101 & 0 & 0 & 1 & 0 \\
\hline OPD-1102 & 0 & 1 & 0 & 0 \\
\hline OPD-1103 & 0 & 0 & 1 & 0 \\
\hline OPD-1104 & 1 & 0 & 1 & 1 \\
\hline OPD-1105 & 1 & 1 & 1 & 1 \\
\hline OPD-1106 & 1 & 1 & 1 & 1 \\
\hline OPD-1107 & 0 & 1 & 0 & 0 \\
\hline OPD-1108 & 1 & 0 & 0 & 1 \\
\hline OPD-1109 & 1 & 1 & 1 & 0 \\
\hline OPD-1110 & 0 & 1 & 0 & 0 \\
\hline OPD-1111 & 0 & 0 & 1 & 0 \\
\hline OPD-1112 & 1 & 0 & 0 & 0 \\
\hline OPD-1113 & 0 & 1 & 0 & 0 \\
\hline OPD-1801 & 0 & 0 & 1 & 0 \\
\hline OPD-1802 & 0 & 1 & 0 & 0 \\
\hline
\end{tabular}

Arab Univ. J. Agric. Sci., 13(2), 2005 
Table 4. Cont.

\begin{tabular}{|ccccc|}
\hline Amplified & \multicolumn{4}{c|}{ Streptomyces strains } \\
\cline { 2 - 5 } fragments & S. lincolnensis & S. venezuelae & S. umbrinus & S. tuirus Si-4 \\
\hline OPD-1803 & 1 & 0 & 1 & 1 \\
OPD-1804 & 1 & 1 & 0 & 0 \\
OPD-1805 & 1 & 1 & 1 & 0 \\
OPD-1806 & 1 & 1 & 0 & 1 \\
OPD-1807 & 0 & 1 & 1 & 0 \\
OPD-1808 & 0 & 1 & 1 & 1 \\
OPD-1809 & 1 & 0 & 1 & 1 \\
OPD-1810 & 1 & 1 & 1 & 1 \\
OPD-1811 & 1 & 1 & 0 & 1 \\
OPD-2001 & 0 & 0 & 0 & 1 \\
OPD-2002 & 0 & 0 & 1 & 0 \\
OPD-2003 & 0 & 0 & 1 & 0 \\
OPD-2004 & 0 & 1 & 0 & 0 \\
OPD-2005 & 1 & 1 & 1 & 1 \\
OPD-2006 & 0 & 1 & 1 & 0 \\
OPD-2007 & 1 & 1 & 1 & 0 \\
OPD-2008 & 1 & 1 & 1 & 1 \\
OPD-2009 & 1 & 0 & 1 & 1 \\
\hline
\end{tabular}

$0=$ Absent. $1=$ Present.

Table 5. Total amplified fragment (TAF) produced via RAPD-PCR using 10decamers primers from the DNA genome of four Streptomyces strains

\begin{tabular}{|cccccc|}
\hline \multirow{2}{*}{ Primers } & TAF & \multicolumn{4}{c|}{ Streptomyces strains } \\
\cline { 3 - 6 } & & S. lincolnensis & S. venezuelae & S. umbrinus & S. tuirus Si-4 \\
\hline OPA-02 & 15 & 10 & 10 & 09 & 09 \\
OPD-01 & 08 & 05 & 04 & 04 & 06 \\
OPD-02 & 08 & 03 & 05 & 05 & 04 \\
OPD-05 & 14 & 09 & 11 & 09 & 09 \\
OPD-06 & 10 & 06 & 06 & 07 & 06 \\
OPD-07 & 19 & 10 & 10 & 11 & 10 \\
OPD-08 & 18 & 09 & 07 & 10 & 10 \\
OPD-11 & 13 & 06 & 07 & 07 & 04 \\
OPD-18 & 11 & 07 & 08 & 07 & 06 \\
OPD-20 & 09 & 04 & 05 & 07 & 04 \\
\hline Total & 125 & 69 & 73 & 76 & 68 \\
\hline
\end{tabular}


Table 6. Unique amplified fragments produced via RAPD-PCR using 10-decamer primers from the DNA genome of four Streptomyces strains

\begin{tabular}{|cccccc|}
\hline \multirow{2}{*}{ Primers } & TAF & \multicolumn{5}{c|}{ Streptomyces strains } \\
\cline { 3 - 6 } & & S. lincolnensis & S. venezuelae & S. umbrinus & S. tuirus Si-4 \\
\hline OPA-02 & 15 & 1 & 0 & 10 & 0 \\
OPD-01 & 08 & 0 & 3 & 1 & 1 \\
OPD-02 & 08 & 1 & 2 & 1 & 0 \\
OPD-05 & 14 & 2 & 3 & 1 & 0 \\
OPD-06 & 10 & 1 & 3 & 0 & 0 \\
OPD-07 & 19 & 1 & 8 & 1 & 1 \\
OPD-08 & 18 & 1 & 3 & 4 & 0 \\
OPD-11 & 13 & 1 & 5 & 3 & 1 \\
OPD-18 & 11 & 1 & 3 & 3 & 0 \\
OPD-20 & 09 & 0 & 2 & 2 & 2 \\
\hline Total & 125 & 9 & 32 & 26 & 7 \\
\hline
\end{tabular}

Table 7. Similarity between four Streptomyces strains based on RAPD-PCR analysis using 10-decamer primers

\begin{tabular}{|lccc|}
\hline \multicolumn{1}{|c}{$\begin{array}{c}\text { Streptomyces } \\
\text { strains }\end{array}$} & S. venezuelae & S. umbrinus & S. tuirus Si-4 \\
\hline S. lincolnensis & 41.0 & 33.9 & 30.6 \\
S. venezuelae & $*$ & 39.4 & 42.0 \\
S. umbrinus & & $*$ & 59.2 \\
\hline
\end{tabular}

Arab Univ. J. Agric. Sci., 13(2), 2005 
Abdel-Fattah

Figure 1. Agarose gel electrophoresis of RAPD-PCR polymorphism of DNA of four Streptomyces strains (S. lincolnensis (A), S. venezuelae (B), S. umbrinus (C) and S. tuirus Si-4 (D)) using OP-A02 (Right) and OP-OD11 (Left). M: DNA marker (1 Kb DNA Ladder).

Figure 2. Agarose gel electrophoresis of RAPD-PCR polymorphism of DNA of four Streptomyces strains (S. lincolnensis (A), S. venezuelae (B), S. umbrinus (C) and $S$. tuirus Si-4 (D)) using OP-D18 (Right) and OP-OD20 (Left). M: DNA marker (1 Kb DNA Ladder). 
Figure 3. Agarose gel electrophoresis of RAPD-PCR polymorphism of DNA of four Streptomyces strains (S. lincolnensis (A), S. venezuelae (B), S. umbrinus (C) and $S$. tuirus Si-4 (D)) using using OP-D01 (Right) and OP-D02 (Middle) and OP-D05 (Left). M: DNA marker (1 Kb DNA Ladder).

Figure 4. Agarose gel electrophoresis of RAPD-PCR polymorphism of DNA of four Streptomyces strains (S. lincolnensis (A), S. venezuelae (B), S. umbrinus (C) and S. tuirus Si-4 (D)) using OP-D06 (Right), OP-D07 (Middle) and OP-D08 (Left). M: DNA marker (1 Kb DNA Ladder).

Arab Univ. J. Agric. Sci., 13(2), 2005 


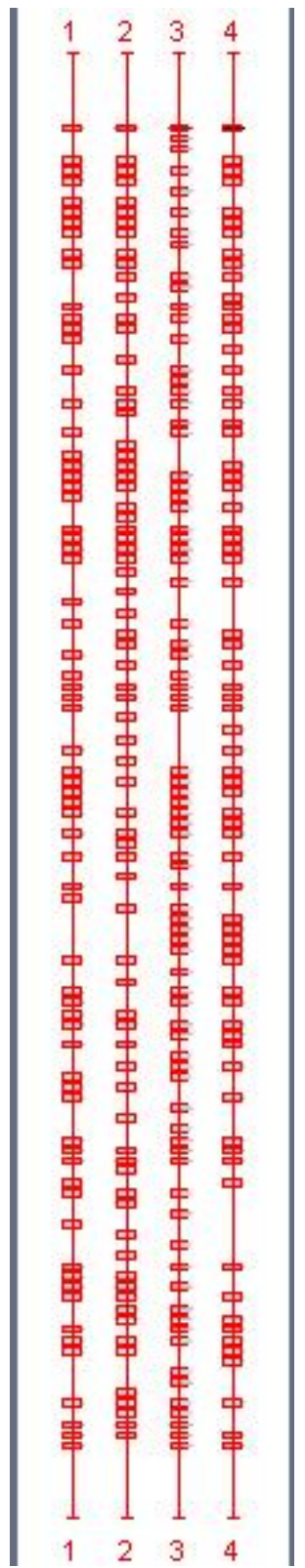

Figure 5. DNA polymorphisms of four Streptomyces strains (S. lincolnensis (1), S. venezuelae (2), S. umbrinus (3) and S. tuirus Si-4 (4)) using based on RAPDPCR analysis. 


$\begin{array}{lllllll}0.36 & 0.50 & 0.60 & 0.70 & 0.80 & 0.90 & 1.00\end{array}$

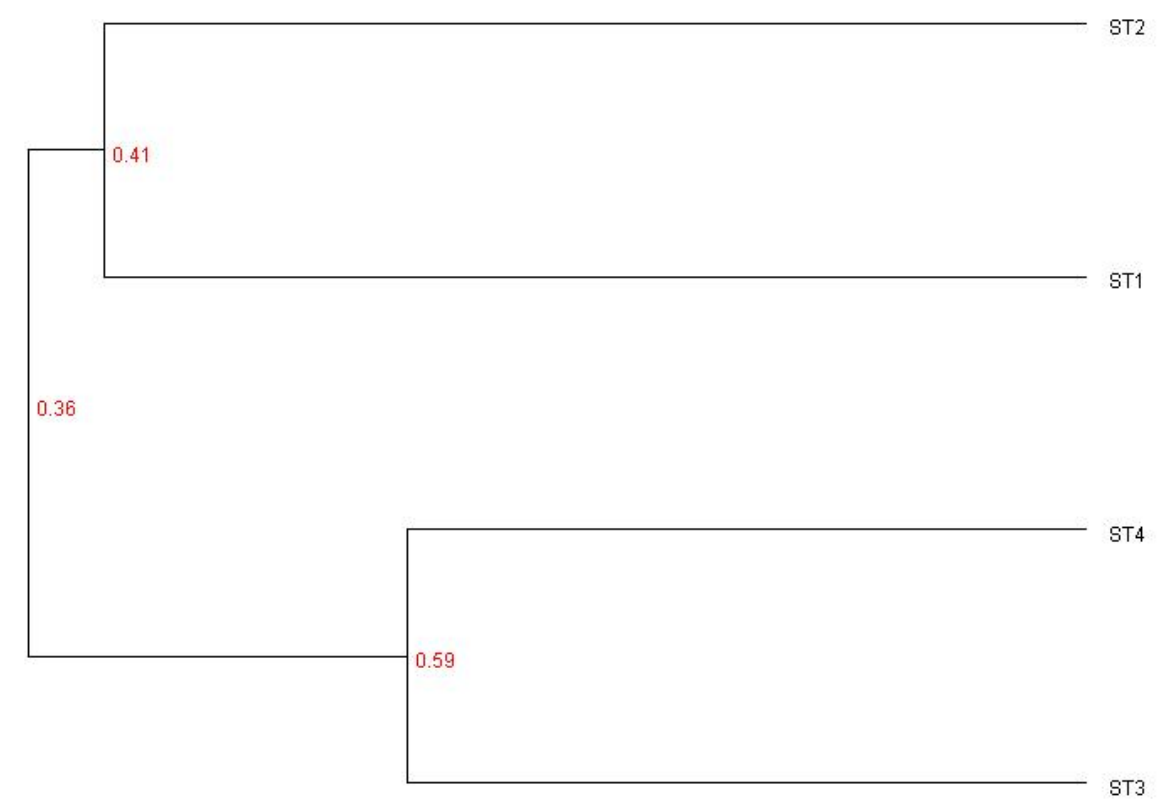

Figure 6. Dendrogram showing molecular relationship between four Streptomyces strains (S. lincolnensis (ST1), S. venezuelae (ST2), S. umbrinus (ST3) and $S$. tuirus Si-4 (ST4)) using 10-decamer primers based on RAPD-PCR analysis.

\section{REFERENCES}

Anderson, M.A.; R. Mikkola and R.M. Kroppenstedt (1998). The mitochondrial toxin produced by Streptomyces griseus strains isolated from an indoor environment is valinomycin. Applied and Environmental Microbiology 64: 47674773.

Brown, T.A. (1990). Purification of DNA from living cells. In: Gene Cloning: An Introduction, pp. 27-42, (Brown, T.A., $2^{\text {nd }}$ Ed.), Chapman and Hall, St. Edmundsbury Press Ltd., London .

Cook, A.E. and P.R. Meyers (2003). Rapid identification of filamentous acti- nomycetes to the genus level using genus-specific 16S rRNA gene restriction fragment patterns. Int. J. of Systematic and Evolutionary Microbiology 53(6): 1907-1915.

Goodfellow, M. and K.E. Simpson (1987). Ecology of Streptomyces. Frontiers of Applied Microbiology 2: 97-125. Kearley, M.J.; J.A. Gow; M. Peloquin and C.W. Greer (1994). Numerical analysis and the application of random amplified polymorphic DNA polymerase chain reaction to the differentiation of Vibrio strains from a seasonally cold ocean. Can. J. Microbiol. 40: 446455. 
Klein, G.; A. Pack; C. Bonaparte; G. Reuter; W.H. Holzapfel; J.H.J. Huisin'-t-Veld; C. Persin and H. Kasper (1998). Taxonomy and physiology of probiotic lactic acid bacteria. International Journal of Food Microbiology 41: 103-125.

Mahfouz, H.T. and Mohamed Sonya H. (2002). Physiological, antagonistic and fingerprinting studies on some halotolerant Streptomyces strains. Arab Journal of Biotechnology 5: 103-120.

Malkawi, H.I.; I. Saadoum; F.A. Moumani and M.M.M. Meqdam (1999). Use of RAPD-PCR fingerprinting to detect genetic diversity of soil Streptomycetes isolates. Biological Control 16 (2): 199-208.

Mehling, A.; U.F. Wehmerier and W. Piepersberg (1995). Application of random amplified polymorphic DNA (RAPD) assays in identifying conserved regions of actinomycete genomes. FEMS-Microbiol-Lett. 128 :119-125.

Mohamed, H. Sonya (1998). Role of Actinomycetes in the Biodegradation of Some Pesticides, p.151. Ph.D. Thesis, Agric. Microbiol., Dept. Agric. Microbiol., Faculty of Agric., Ain Shams University, Cairo.

Mohamed, H. Sonya; Sh.M. Selim and E.A. Saleh (2000). Taxonomical and biochemical studies on some halotolerant actinomycetes isolated from sandy soil in Egypt. Arab Univ. J. Agric. Sci., Ain Shams Univ., Cairo, Egypt, 8(1): 4161.

Mohamed, H. Sonya; H.I. AbdelFattah; Sh.M. Selim and M.S. Sharaf (2001). Identification and molecular studies on some halotolerant actinomycetes isolated from Sinai sandy soil. Arab Journal of Biotechnology 4: 179. 196.
Nava, V.R.; A. Couble; E. Casoli; U. Bugnard; F. Laurent; H. Sandoval; and P. Boiron (2001). Identification of clinical isolates of Streptomyces spp. using the polymerase chain reaction. Joural de Mycologie Medicale 11(3): 131-134.

Nei, M. and W.H. Li (1979). Mathematical model for studying genetic variation in terms of restriction endonuclease. Proceedings of the National Academy of Sciences of the United States of America 76: 5269-5273.

Porteous, L.A.; J.L. Armstrong; R.J. Seidler and L.S. Watrud (1994). An effective method to extract DNA from environmental samples for polymerase chain reaction amplification and DNA fingerprint analysis. Current Microbiology 29(5): 301-307.

Pridham, T.G. and H.D. Tresner (1974). Family Streptomycetacae. In; Bergey's Manual of Determinative Bacteriology (1974), p751, 793, 802, 826. (Buchanan R.E. and N.E. Gibbons, $8^{\text {th }}$ Ed.), Williams and Wilkins Co., Baltmore, USA.

Raad, G.; S. Ismail and M. Amjad (2003). Genotypic and phenotypic characteristics of antibiotic producing soil Streptomyces investigated by RAPDPCR. Journal of Basic Microbiology 43(1): 18-27.

Rintala, H.; A. Nevalainen and M. Suutari (2002). Diversity of Streptomyces in water-damaged building materials based on $16 \mathrm{~S}$ r DNA sequences. Letters in Applied Microbiology 34(6): 439443.

Rohlf, F.J. (1990). NTSYS-pc, Numerical Taxonomy and Multivariate Analysis System, Version 1.60, pp.10-35. Exeter Software Publisher, Seteutet, New York . Saleh, E.A.; M.E. El-Haddad; S.A.Z. Mahmoud; M.K. Abdel-Fattah and 
Sawsan F. Shehata (1985). Studies on the enzymatic activities of some local streptomycete isolates. Proc. Egypt. Bot. Soc. Ismailia Con. 16-19 April, 1985. Egypt, Part 1, No. 4: 10-14.

Saleh, E.A.; M.M. Zaki; M.E. ElDemerdash and Sonya H. Mohamed (1990). Identification of some halotolerant streptomycetes isolated from marine ecosystems in Egypt. Annals of Agric. Sci., Ain Shams Univ., Cairo, Special Issue, 409-425.

Sambrook, J.; E.F. Fritsch and T. Maniatis (1989). Gel electophoresis of DNA .In: Molecular Cloning: A Laboratory Mannual, Part 6, pp. 1-15, $2^{\text {nd }}$ Ed. Cold Spring Harbor Laboratory Press, Cold Spring Harbor, New York.

Shirling, E.B. and D. Gottlieb (1966). Methods for characterization of Streptomyces species. Int. J. Syst. Bacteriol. 16(3): 313-340.

Sony, J.; S. Lee; J. Kang; H. Baek; J. Suk; S.C. Song; J.W. Kang; H.J. Baek and J.W. Suh (2004). Phylogenetic analysis of Streptomyces spp. isolated from potato scab lesions in Korea on the basis of $16 \mathrm{~S}$ rRNA and $16 \mathrm{~S}-23 \mathrm{~S} \mathrm{r}$ DNA internally transcribed spacer sequences. Int. $J$. of Systematic and Evolutionary Microbiology 54(1): 203-209.

Srinivasan, M.C., R.S. Laxman and M.V. Deshpande (1991). Physiology and nutritional aspects of actinomycetes: an overview. World J. Microbiology and Biotechnology 7: 171-189.

Strohl, W.R. (1997). Industrial antibiotics: today and the feature. In: Biotechnology of Antibiotics. $2^{\text {nd }}$ Ed. pp. 1-47. Marcel Dekker W.R. Stroh (Ed), New York.
Tolba, S.; S. Egan; D. Kallifidas; E.M.H. Wellingaton (2002). Distribution of streptomycin resistance and biosynthesis genes in Streptomyces recovered from different soil sites. FEMS. Microbiology Ecology. 42(2): 269-276.

Waksman, S.A. and H.A. Lechevalier (1961). Classification, identification and description of genera and species. In: The Actinomycetes. Vol. II p. 340., The Williams and Wilkins, Co., Baltimore, USA. Weigler, B.J.; J.E. Thigpen; M.F. Goelz; C.A. Babineau; D.B. Forsythe (1996). Randomly amplified polymorphic DNA polymerase chain reaction assay for molecular epidemiology investigation of Pasteurella pneumotropica in laboratory rodent colonies. Laboratory Animal Science 46:386-392.

Williams, J.G.K.; A.R. Kubelik; K.J. Livak; J.A. Rafolski and S.V. Tingey (1990). DNA polymorphisms amplified by arbitrary primers are useful as genetic markers. Nucleic Acids Research 18: 6531-6535.

Wirth, S. and A. Ulrich (2002). Cellulose-degrading potentials and phylogenetic classification of carboxy methylcellulose decomposing bacteria isolated from soil. Systematic and Applied Microbiology 25(4): 584-591.

Zaki, M.M.; E.A. Saleh; M.E. ElDemerdash and Mohamed Sonya $H$. (1993). Antimicrobial activities of some halotolerant streptomycete strains as affected by incubation period and medium composition. $4^{\text {th }}$ Conf. Agric. Dev. Res., Ain Shams Univ., Cairo, Feb. 13-18, 1993. Annals Agric. Sci., Sprcial Issue, 2: 519-529. 
بحلة اتحاد الجامعات العربية للدراسات والبحوث الزراعية ، جامعة عين شمس ، القاهرة ، 13(2) ، 249 - 268 ، 2005

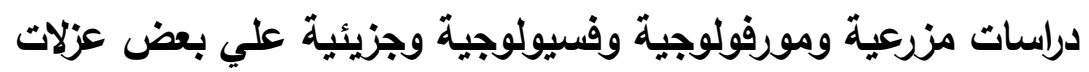
الأستربتوميسيسات

[15]

\section{حسن ابراهيم عبد الفتاح'}

1- قسم الميكروبيولوجيا الزراعية - كلية الزراعة - جامعة الزقازيق - الزقازيق - مصر الفئ

و إيضـاحها بالصبغ بواسطة الأيثيديم بروميد البنان

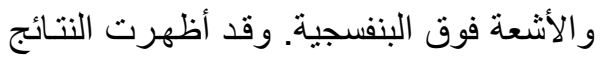

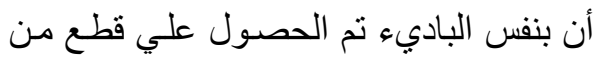

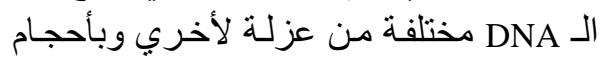

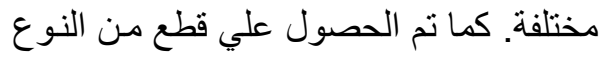
Polymorphic Momorphic العلاقـة و التقـارب علـي المسـتوب الجزيئي

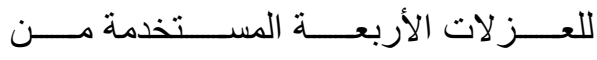

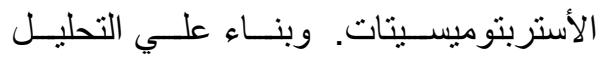

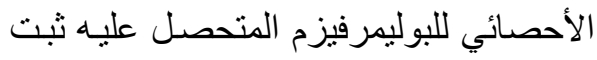

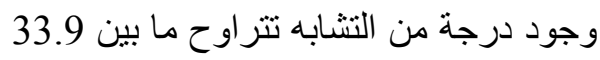
الي 59.2 \% للأنواع الأربعـة لنفس الجنس.

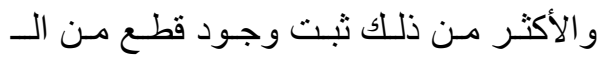

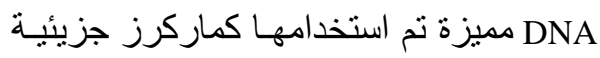
والتي يمكن استخدامها للتميز بين العزلاتهات التهات

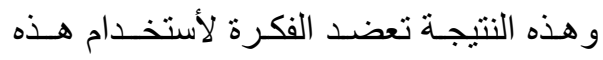

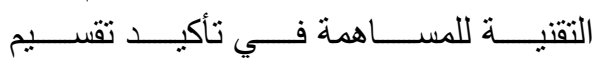
الأستربتو مايسيسات.
في هذه الدر اسة تم تعريف ثناثة عزلات

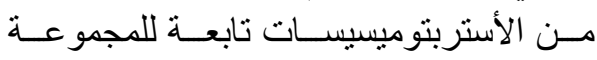

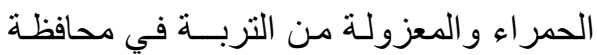

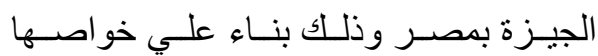

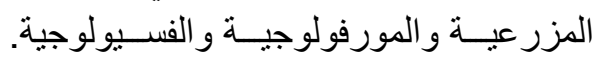

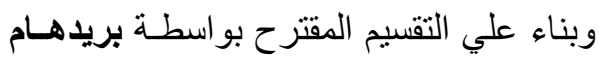

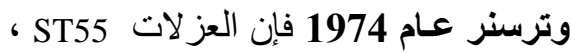
S. اتضح ST86 ST71 S. umbrinus dincolnensis, S. venezuelae علي التو الي. وبالإضافة الي ذلك تم استخدام

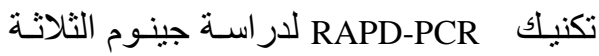
عزلات المستخدمة لتقدير البصـمة الور اثيـة

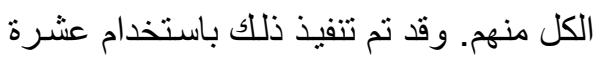
من البادئات هي: OP-A02, OP-D01, OP D02, OP-D05, OP-D06, OP-D07, OPOP-D20, D08, OP-D11, OP-D18 وقد تم

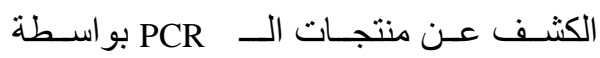

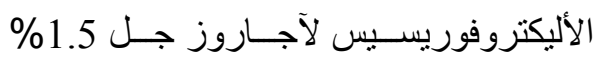

تحكيم: أ.د السيد أحمد صالح أ. أ.د سمير حماد سالم 